\title{
To Join or Not to Join, and How to Join: Higher Education as an Option in the Israeli Haredi World Today
}

\author{
Nitza Davidovich (Correspondent Author) \\ Quality Assessment and Academic Instruction, Ariel University \\ POB 3, Ariel 40700, Israel \\ E-mail: d.nitza@ariel.ac.il
}

Dan Soen

Department of Sociology, Ariel University

POB 3, Ariel 40700, Israel

$\&$

Kibbutzim School of Education

Tel-Aviv, Israel

Received: October 29, 2014 Accepted: November 14, 2014 Published: November 28, 2014

doi:10.5296/iss.v2i2.6699

URL: http://dx.doi.org/10.5296/iss.v2i2.6699

\begin{abstract}
The State of Israel is gradually increasing its efforts to integrate the ultra-Orthodox population within Israeli society both in general (in the army, in employment) and in higher education in particular. The major question arising in all systems where attempts are being made to integrate this population is whether they should be encouraged to join separate settings or existent settings, together with the rest of the population. This question is at the heart of the current article. The article suggests that policy shapers in Israeli higher education object to establishing unique institutions for the ultra-Orthodox; their integration in existing settings as well should only serve as an intermediate solution. The solution devised by the CHE (Council for Higher Education) is the "platform" or "inn" institution - a Haredi or ultra-orthodox institution of higher education operating under the academic wings and direct
\end{abstract}




\section{Macrothink}

Issues in Social Science ISSN 2329-521X 2014, Vol. 2, No. 2

control of an existing and recognized academic institution. At present it seems that despite forecasts regarding the significance of providing accessibility to higher education for the ultra-Orthodox in Israel, we will probably witness a similar process to that which occurred in Israeli higher education in the 1990s, one of universalization and popularization. At first there will be a significant rise in the proportion of ultra-Orthodox joining the system and then the numbers will level out.

Keywords: higher education, Jewish education, Haredi, Israel, accessibility 


\section{Introduction}

Until the early twentieth century, institutions of higher education in Western society served as a tool for training religious, social, and political elites. Thus, for example, the Bachelor's program in nineteenth century US was a standard setting that trained its students for a career in the law and the clergy (Blackburn \& Conrad, 1986; Kockelmans, 1986). The schools were usually an organ of the church, expected to display appropriate theological conceptions. In the US, privately owned academic institutions began to emerge in the early seventeenth century; however this trend did not manage to expand the applicability of academia and to integrate it within daily life (Thelin, 2011). The universities remained closed elite institutions with limited social goals. Towards the end of the eighteenth century and the beginning of the nineteenth century, the world began to experience processes of secularization and embracing of the civil nation-state. These processes had an effect on the development of the modern "civic university" (Agion, Dewatripont, Hoxby, Mas-Colell, \& Sapir., 2008; Johnston, 1998), which transitioned from a religious to a secular institution. Higher education, in the past exclusively controlled by religious institutions, became a symbol of secular and modern life. Once the secular component of higher education became dominant, unique institutions were established by groups seeking to preserve a religious orientation within academia and to combine secular and religious studies (Ganss, 1954; Litfin, 2004; Schuman, 2010). All over the world there was a rise in the number of religious institutions and in the number of students enrolling in these institutions (Arthur, 2008), with the wide goal of transposing students' religious identity (Sharma \& Guest, 2013) on certain aspects of academic life (special courses, centers, chairs) and thus creating a type of sub-culture within the world of higher education (Arthur, 2008).

In Israel as well, self-defined as a Jewish State with no separation of church and state, a religious university was established with the aim of meeting the unique needs of the Jewish Orthodox population. This university, called Bar-Ilan, was established as a religious college through a private-political initiative, based on the ideology of the National Religious Party (known by its acronym MAFDAL). The impetus for this endeavor was the need for a school of higher education to serve national-religious youth, teaching both general disciplines and subjects with significance for the religious ideology (Schechter, 2006). Unlike other institutions, Bar-Ilan was intended to be an institution "striving to create researchers and scholars and people of general culture who would be sons of Torah and lovers of Torah and its guardians with no conflicts and with no internal deliberations. Jewish intellectualism cannot exist without the Jewish Torah" (Churgin, 1953 cited in Bar Ilan University, 2014). At present, more than sixty years after Bar-Ilan sought to become an umbrella institution for the religious population, it is a "university for everyone," with an equal proportion of religious and secular students, where both populations manage to study side by side.

Since the 1950s, another religious group with unique features has gro wn considerably. This is the group of ultra-Orthodox (Haredi), transformed from a negligible minority to a significant segment of the population (Ravhon \& Malach, 1999), by 2003 reaching 10 percent of the 20+ age group among Israel's Jewish population (Friedman et al., 2011). Both government agencies and members of this community are of the opinion that the demand that this 
population become integrated within existing programs of higher education contradicts the principle of equal opportunities. From the late 1990s, when Haredi attitudes to higher education reached a turning point, the State of Israel began acting to form unique study channels that would enable this group to acquire a higher education. In the last two years ten designated academic settings for the Haredi population (MACHARs) were established, following the principles formulated by the PBC (Planning and Budgeting Committee of the Council for Higher Education). These operate under the full patronage of recognized institutions of higher education (CHE/PBC, 2014). The purpose of the current article is to examine this decision with consideration of historical aspects, to explore current and future trends, and to discuss the costs and benefits of opening designated institutions and programs for the Haredi community in Israel.

\section{Haredi Society -Historical Background}

The roots of current-day Haredi society may be found in nineteenth century Hungary, where it first began to emerge in response to processes of secularization and modernization embraced by many contemporary European Jews (Finkelman, 2011; Friedman, 1991). Historian Jacob Katz $(1984 ; 1992)$ perceived the Haredi way of life as a post-traditional phenomenon formed in response to dogmas that found their way into traditional Jewish communities in Europe following the emergence of modernity. The culture war waged by the religious leadership between the old and new orders generated a fundamentalist response Haredi orthodoxy (Almog, 2012; Friedman, 1991). The Haredi stream, also called "ultra-Orthodox," follows a religious conception that seeks to preserve religious life in the closest possible form to its initial sources, while avoiding any change of Jewish law and of the Bible (Caplan, 2007; Finkelman, 2002; Shahak \& Mezvinsky, 1999). The Haredi world view is conservative and puritanical and it defines itself in terms of a "counter-culture." This means that it embraces a world view and a way of life that stress its extreme difference from surrounding society and its moral superiority over others (Katz, 1984, 1992; Neugershal, 2002; Zicherman, 2014). This society nurtures an ascetic ethos, setting its spirituality in contrast to the materialism of surrounding secular society (Stadler, 2003). The conceptions held by this group led to its cultural segregation from surrounding society (Spiegel, 2013).

In order to protect itself from the external influence of modernization and secularization, this society founded an educational-cultural system that strictly maintains Jewish law, objects to modernity, to Enlightenment, and maintains communal segregation (Caplan, 2007; Fried man, 1991; Katz, 1984; Malach \& Cohen, 2011). This segregational approach received enhanced meaning after the Holocaust and once the State of Israel was founded, in light of the concern of the Haredi leadership that Haredi society would become weakened and die out. In response, beginning from the 1950s the Haredi leadership promoted Torah study as the exclusive occupation of men in their community. Up to that time, Torah study was considered an important precept, as it says in the Gemara: "If not for the Torah, heaven and earth could not be sustained" (Babylonian Talmud, Tractate Pesachim 68b), however only very few engaged in this pastime exclusively and most of the faithful were required to combine Torah study with work (Spiegel, 2011, 2013).

In the 1950s, the Chazon Ish (Rabbi Avraham Yeshaya Karelitz) - among tho se who headed the movement towards transforming the idea of Torah study into an ultimate way of life - set 
a goal of increasing the number of Torah scholars. He sought to turn this way of life into a collective norm rather than the occupation of a selected few (Spiegel, 2011, 2013). In this way, with the financial support of the State and the spiritual support of community leaders, the number of students in Haredi society gradually rose until reaching gargantuan proportions in the early 1990s, earning Haredi society the designation of a "Society of Learners" (Hevrat halomdim) (Friedman, 1991). Recognizing Torah study as the Haredi answer to the secular world and the exclusive pastime of men in this community was a precedent, unparalleled among contemporary Haredi communities outside Israel (Caplan, 2010) - In a matter of three decades the unemployment rate among Haredi men in Israel grew more than 3-fold, and the number of yeshiva students rose by 60 percent (Regev, 2013)

The growth of the Society of Learners was attended by renewed interpretations of Jewish law, confirming a way of life demanding absolute devotion to Torah study at the expense of the place and significance of labor. This weakened motivation to acquire a higher education and created significant knowledge gaps between the Haredi community and the general population, due to the absence of core studies (Regev, 2013). As a result of the resistance to becoming integrated in the labor market and of perceiving secular studies as contrary to the Torah ideal, government decision makers perceived the integration of members of the Haredi community in schools of higher education as an impossible mission. Indeed, members of the community were almost completely absent from Israel's academic sphere from the establishment of the State until the early 2000s (Knesset, 2014). Nevertheless, in contrast to the proclaimed ideological position and in a fairly clandestine movement, this state of affairs has been changing gradually. Over the past two decades, unacknowledged by the secular public, members of the Haredi community have changed their attitude to higher education and, as a result, a change is now evident in the attitude of government policy shapers as well.

\section{The Haredi Community in Israel and its Attitude to Higher Education}

At present, the Haredi community in Israel numbers between 600 and 800 thousand according to different estimates. This population comprises 8-9 percent of Israel's Jewish population, with a mean annual gain of 7 percent (CHE, 2012b). Despite the extent of Haredi society, until the late 1990s Haredi academic students numbered only a few dozen and they constituted less than 1 percent of all students at institutions of higher education (Knesset, 2014). The absence of Haredi students from the academic sphere has been given a variety of explanations in the literature, including: resistance to becoming integrated within Israeli society, difficulty with becoming integrated in existing secular institutions due to life style differences, the many "kollels" (Torah study settings for married men) and the belief that Torah study should be the exclusive pastime of Haredi men, as well as the difficulties stemming from the very low level of basic education, particularly English studies, in the Haredi curriculum (Knesset, 2014).

Despite the official attitude objecting to higher education, since the 1960s two academic institutions with a Haredi orientation have been operating (The Jerusalem College for Girls for women and the Jerusalem College of Technology (Machon Lev) for men). These institutions perceived themselves as belonging to the Haredi stream, while embracing an approach of "Torah with the way of the land" (torah im derekh eretz). According to the Haredi approach, encouraged by Rabbi Avraham Yeshaya Karelitz (the Chazon Ish) in the 
1950s, the Torah includes all wisdoms in the world and therefore any preoccupation with external knowledge or wisdom was perceived as contradicting its wide scope (the "Torah only" approach). In contrast, those advocating "Torah with the way of the land" have a positive approach to science and secular studies. This approach is evident in the Rambam's philosophy, whereby only through secular studies can believers understand the relationship between the world and its Creator. As perceived by the Rambam, secular studies are also essential for performing the practical commandments (Lupo, 2003). The first Haredi institutions in Israel that did not receive the support of the main stream operated in accordance with this outlook (Malach, 2014). As mentioned above, these first two institutions were the Jerusalem College for Girls (Michlala) for women, established in 1964, and the Jerusalem College of Technology (Machon Lev) for men, established in 1969 (Malach \& Cohen, 2011). Despite the lack of support, the few Haredi men and women who chose to acquire a higher education applied to these two institutions.

In the 1990s, the understanding that these two institutions were no longer sufficient began to grow, and the need to expand options for higher education within the Haredi community became evident. Malach (2014), in his comprehensive research on academic studies in the Haredi sector and in an article with Cohen (Malach \& Cohen, 2011), described four conditions that led to the emergence of this need at that specific point in time: (1) Demographic growth of Haredi society - a rise in the natural growth of the Haredi population, with a concurrent reduction of government support. These two together created pressure to earn a living. (2) Academization of the labor market - academic degrees became a condition for adequately paid jobs. (3) Discontent of sub-groups in Haredi society with the existing situation - Diversification of Haredi society created sub-groups that wished to preserve their way of life while also acquiring an academic degree and a respectable profession national-Haredi, Haredi people of Eastern origin, young Haredi people, and women, were among the sub-groups striving for change. (4) Saturation of the Haredi labor market in the field of teaching - Training institutions for women were directed mainly at careers in teaching. At a certain stage the supply exceeded demand, with consequent unemployment. This created pressure to diversify women's fields of study, with the goal of creating additional career routes. The first to rise to the challenge were Haredi politicos, and later on government agencies joined efforts to integrate members of the Haredi community in academia.

\section{Initial Forays in the World of Higher Education}

Paradoxically, it was the increasing power of Haredi society and the success of the Torah study enterprise that led to the changing attitudes towards higher education. In 1996, Shas (a political party established by Haredis of Oriental descent) became the Israeli political party with the third largest representation in the Knesset, but it encountered difficulties with filling some of the available positions as many people did not meet the officially required academic threshold conditions. In that year, known as the year of the "dramatic change" (Lupo, 2003), initial attempts at establishing a Haredi academy commenced. In those days, Shas unofficially approached the heads of the Hebrew University (Lupo, 2003) in order to examine the possibility of academic studies for the Haredi community, to include four elements: studying practical professions that would be able to provide a source of subsistence; appealing to Haredi people who no longer study Torah; gender separation; and Rabbinic approval of the 
program (Malach, 2014). Negotiations with the Hebrew University failed when the university refused to compromise its academic standards, despite its readiness to accept the program's features, which later constituted the basic outlines of Haredi institutions and study programs (aside from rabbinic approval of the program).

In contrast to the Hebrew University, the Israeli branch of Touro College, with whom Shas entered into a process of negotiations as well, agreed to grant Haredi students favorable conditions. Thus, a study program for Haredi students was launched, consisting of evening school once or twice a week and concentrated study days during yeshiva vacations (Malach, 2014). In a short time, over 250 Haredi candidates applied to the branch. The program operated for six cycles, with a total of 322 students. In 1999, following a CHE decision whereby degrees awarded by branches of foreign institutions would no longer be automatically recognized, the branch was closed. At that time, the Hebrew University agreed to operate an experimental social work retraining program at the Haredi College Neve Yerushalayim. The program, opened in 1997, closed after two cycles, when the university claimed that the college students had an insufficient professional and academic background (Malach, 2014).

Despite the ultimate failure of these attempts, they indicated the potential of providing accessibility to higher education for the Haredi population, a potential of which the CHE was aware, and in 1999 it decided to open three branches of the Jerusalem College of Technology. These operated under the patronage of Bar-Ilan University. At the same time Shas continued to promote its efforts to establish an independent Haredi college. As part of the attempt to establish a Haredi college, they recruited Adina Bar-Shalom, daughter of Rabbi Ovadia Yosef, (the leader of Shas), to the Tze U'lmad association, founded with the aim of encouraging academic studies among the Haredi public. Bar-Shalom urged recognition of an independent Haredi college, until in late 2000 the CHE approved the study program she proposed and in 2001 the Orthodox Jerusalem College began operating, under the patronage of Bar-Ilan University. The model led by Bar-Shalom was not the independent model initially sought. The CHE, despite its fundamental support of opening higher education to the Haredi community, rejected the idea of establishing a Haredi college outright and, instead, embraced the "platforms model."

\section{The Platforms Model}

As stated, the CHE supported the expansion of higher education institutions for the Haredi community. For example, the document composed by Prof. Nehemya Lev Zion towards the first discussion of the Haredi community in 1999 began thus: "The entrance of members of the Haredi population to academic studies, and then to the world of employment, is a historical shift with social and economic implications" (Lupo, 2003, 72). The CHE sought, on one hand, to enable the Haredi population to receive unique adjustments and needs, and on the other to maintain the high academic level of the curriculum. Interestingly this approach, of adapting institutions according to the features of the population, is not customary elsewhere. Studies conducted among fundamentalist social groups in the US found that the groups (rather than the institutions) are those that must show flexibility and compromise in order to become integrated in the world of higher education (Levy, 2013). Nonetheless, the CHE decided that the best solution that would enable adjustment to the religious life style 
while maintaining the standards of the academic program is to create platform institutions independently managed settings that would form the organizational infrastructure for the activity of recognized academic institutions (Levy, 2013). These institutions, also called "inns," or MACHARs as designated by the CHE (CHE/PBC, 2014), are branches of recognized academic institutions. The degrees awarded by the branches are given by the parent school (Malach \& Cohen, 2011). At these institutions, government-budgeted universities and colleges offer regular programs in which graduates earn Bachelor's and Master's degrees in several disciplines (Knesset, 2014). In this model, the campus management is responsible for the organizational aspects of the institution while the parent schools are responsible for the study programs and the faculty (Malach, 2014). In the 2014 school year, over 1,600 students were enrolled in these MACHARs (CHE/ PBC, 2014).

Among the platform institutions are the Bnei Brak College, which operates under the patronage of the Universities of Haifa, Tel Aviv, and Bar Ilan, and the Orthodox Jerusalem College, which operates under the patronage of Bar-Ilan Univrsity, the Open University, and the Hadassah Academic College. In the 2013 school year, 2,062 students were enrolled in both schools together, of them 1,611 women and the rest men (Knesset, 2014). Following the success of the platforms, since 2005 several non-budgeted colleges have opened study settings for the Haredi public, operating as branches of the colleges. These institutions include the Haredi track of the Ono Academic College (2002), the Haredi branch of the Lander Institute (2009), the Haredi branch of the Carmel Academic Center (2009), and the Haredi branch of the Safed College (2009). The rise in the number of Haredi students and the flourishing Haredi branches and programs are mutually productive and it seemed that there was no going back - the dam had broken and the ban on higher education for the Haredi population had been removed. By 2012, the number of Haredi students at the various schools of higher education had exceeded 7,000.

\section{MACHARs - Unique Academic Settings for the Haredi Population}

The integration of the Haredi population in Israel's system of higher education was described by the CHE as a "national challenge" with many implications for Israeli society and economy (CHE, 2012b). The CHE, in its various publications, enumerated a list of obstacles encountered by Haredi people seeking to join academia: "A concern of leaving the familiar settings for a new setting, coping with knowledge gaps and academic study habits, coping with financial difficulties, adjustment to features of the competitive labor market, are only some of the difficulties encountered by a Haredi person interested in academic studies" (CHE, 2012b, 62). In 2012 the CHE published a new program with the aim of coping with these obstacles. In this document it asserted that in light of the principle of equal opportunities it is necessary to establish separate higher education settings for the Haredi community, since: offering academic studies to the Haredi population only within regular settings breaches the principle of equal opportunities, in light of the knowledge gaps and cultural barriers. Equal opportunities require separate study settings that will provide a response to the disparities and the barriers (CHE, 2012a).

In order to promote the MACHAR project the PBC, together with the Ministry of Finance, allocated some NIS 180 million, a sum to be provided gradually by 2016. The program presented by the CHE called for the establishment of "unique academic settings for the 


\section{MInstitute ${ }_{\text {Int }}^{\text {Macrothink }}$}

Issues in Social Science ISSN 2329-521X 2014, Vol. 2, No. 2

Haredi population," to be located beside and directly supervised by existing academic institutions. The government budgeted institutions were called upon to present programs for opening MACHARs that would refer and provide a response to the following aspects: geographical proximity to Haredi populations; manner of student recruitment; variety of disciplines and academic envelope; plan for rise in the number of students and academic development; plans for career placement and for ability to raise donations for student scholarships (CHE, 2012b). In 2014, following the call by the CHE, 15 MACHARs were opened throughout Israel, offering varied study programs (see Appendix 1).

Since the initial attempts in 1996 and until the present, the number of Haredi students has grown from several dozen to over 7,200. Between 2004 and 2014, a rise of over 600 percent was noted in the rate of Haredi students at institutions of higher education (Malach, 2014). The number of current institutions and tracks offering higher education for Haredi students is in the dozens, compared to the two single schools that existed until the 1990s. The success of the project for providing accessibility to higher education for Haredi students is currently arousing a debate on the price that this project might have for society in social and economic terms. The debate centers on the question of whether it is right to encourage separate settings or should the goal be to integrate Haredi students in existing settings?

\section{Accessibility of Higher Education for Haredi Students and Its Price}

According to CHE forecasts, by 2016 some 8,000 Haredi students will be studying at institutions of higher education. Notwithstanding this impressive achievement there is still, as stated, a wide debate (Note 1) on the issue of whether Haredi students should be integrated in existing academic settings or whether separate gender-divided settings should be formed. As mentioned above, research from around the world shows that fundamentalist groups who wish to become integrated in both higher education and employment settings are normally those required to compromise and show flexibility (Shahak \& Mezvinsky, 1999). Nonetheless, unique institutions of higher education for certain religious groups exist in various models in other countries, in an attempt to enable integration in higher education while maintaining their religious identity (Arthur, 2008).

As stated, in Israel the PBC devotes many efforts and resources to providing accessibility to higher education for the Haredi population by forming sub-campuses within existing institutions. The CHE's guidelines are: recognition of the unique features of the Haredi population; their integration in academia with respect for their way of life and providing an adequate response to their needs and aspirations; recognition of the wide variety within the Haredi sector for which different solutions are offered (CHE, 2012b). These guidelines are the underpinnings of the "five-year plan" introduced by the CHE in 2010. This program set goals of increasing the number of Haredi students in academia by more than 3,000 and increasing the number of Haredi students in pre-academic programs by 750 . At present, towards the end of 2014, it is already possible to say that these goals have been fully met. In 2010, before the five-year plan was launched, nearly 2,000 Haredi students were studying in Israel's system of higher education, while today, five years later, their numbers $-7,700-$ have exceeded all the CHE's forecasts and plans.

It is precisely the sharp rise in the number of Haredi students (see Appendix 2) which has led to the growing public and academic discourse on the meaning and price of providing 
accessibility to higher education for the Haredi sector. Some claim that the overwhelming success of the program entails a risk for Israeli society. For example, according to the protocol of the CHE meeting in 2013, Prof. Ran Hermesh of Ben Gurion University claims (Hermesh, 2014) that if the current trend will continue the program's success will have a negative effect both on academia and on the labor market. He says that academia will suffer as a result of the high demand for lecturers, which will harm the regular system and cause a gender bias among the faculty. Additionally, Hermesh is of the opinion that the composition of the students in the regular systems will also be negatively affected due to the inclination of religious Zionists to prefer these settings, as evident in other instances (for example, the Haredi Nahal military service). With regard to the labor market, he claims that a certain segment of Haredi students will remain unemployed since the economy is incapable of offering gender divided employment opportunities. The separation introduced by academia in an effort to make higher education more accessible for Haredi students, says Hermesh, will "eventually lead to a demand to introduce system-wide segregation... the result will be the building of walls rather than creating integration" (Council for Higher Education protocol of the CHE meeting, 2013).

Prof. Rona Kuperman, Rector of the Hebrew University, also objects to the plan of forming separate settings for Haredi students. Her claim is different: that these create norms of women's exclusion that then trickle over to Israeli society in general (Council for Higher Education protocol of the CHE meeting, 2013). Dr. Yofi Tirosh, lecturer on labor and discrimination laws, joins this approach and says that creating gender division of academic studies intended for Haredi society will recreate separation between men and women in the economy. Despite the significance of the project, Tirosh states, it is necessary to think of its price for Israeli society: "Integrating the Haredi population in higher education and in Israeli society is a project of first rate national importance, but it must be implemented wisely. It is necessary to solve problems but also to think of the price. We must integrate the Haredi population within Israeli society but we must think of the proper way; educating the Haredi population is important but in many of the colleges women cannot study business administration and law and men are unable to study music therapy. Moreover, female lecturers and their freedom of occupation are already restricted. Less accredited male lecturers are employed because they can teach both men and women while women can't teach men" (Council for Higher Education protocol of the CHE meeting, 2013).

In contrast, those in favor claim that there is no other way of integrating Haredi students, as they will not attend regular settings: "It is necessary to adapt the appropriate platform for the Haredi public - institutions adapted to the Haredi way of life will manage to operate" (MK Yaakov Asher, cited in CHE meeting protocol, 2014). Adina Bar-Shalom, CEO and founder of the Orthodox Jerusalem College, joins this approach and claims that it will not be possible to enforce secular studies on Haredi students, rather this must be done in a way appropriate for them (Bar Shalom, cited in Pundak, 2013). Bar Shalom noted that to date "those who addressed higher education for Haredi students sought the common element rather than the divisive element. And today the divisive is greater than the common" (Bar Shalom, cited in Pundak, 2013). In a position paper published by Zatcovetsky and Gal (2012) on how to integrate Haredi students, they claimed that with regard to higher education, creating a 
separate system for Haredi students is an essential condition, at least in the first stages of higher education. In their opinion, it becomes more meaningful the more students advance in their studies. In summary, it seems that the more successful the plan to provide accessibility to higher education for the Haredi population, the more public attention it is attracting. This attention includes a list of advocates and opponents. While everyone agrees on the significance of integrating religious populations in higher education, there are differences of opinion on how this goal should be realized.

\section{Discussion}

The modern system of higher education is based on obtaining objective scientific knowledge while distinguishing between rationalism and between feelings and emotions as a barrier to truth. This is a significant factor hampering and preventing the integration of fundamentalist religious groups in academia, due to the concern of conflict and clashes between the values and faith principles of the religious group and the academic schooling provided (Malhi, 2010). Haredi society too, as a fundamentalist group, seeks to protect itself as much as possible from external influences. This matter transforms the issue of Haredi entrance into the world of higher education to one that is both complex and intriguing.

One of the prominent features of the Haredi approach is its strong resistance to higher studies, resistance originating from Europe in the Enlightenment Period (Malach, 2014). Nevertheless, the ongoing process in the last two decades indicates that despite their official attitude, cracks are appearing in the wall the Haredi community erected between themselves and the world of higher education. One manifestation of this change is evident in the attitudes of yeshiva students to academic schooling. Lupo and Malhi (2011) found that 30-31 percent of yeshiva students declared that they do not see themselves remaining in the "Torato umnuto" (Torah as one's main occupation) track and that they wish to study and acquire a profession or an academic degree that will help them support themselves in the future. In a survey conducted in 2006 among the Haredi Community of Learners, some 60 percent of respondents declared that they are interested in obtaining academic schooling; 20 percent went even further and said that they were willing to study in academic settings not specifically designated for Haredi students (Malhi, Cohen, \& Kaufman, 2008). Lupo and Malhi further show that yeshiva students and their parents are willing to consider an educational course that affords exposure to mathematics and English in high school, in order to be able to study for a profession or an academic degree in the future. The researchers claim that this finding shows that students are already aware that the absence of these subjects at this stage in their life will be detrimental for them in the future. Furthermore, this may indicate that Haredi society has matured to a certain degree and is ready to enter higher education.

The initial incentive was the existential need for subsistence. This need joined the needs of the Israeli economy and the wish for the Haredi population to become integrated in Israeli society. This incentive is also encouraging the gradually increasing enlistment of Haredi men in the IDF in order to obtain a profession (Cohen, 2010). As perceived by decision makers and policy shapers, the Haredi entrance into higher education is an "admission ticket" to Israeli society, in light of the recognized association between level of education and employment rates (Regev, 2013). The CHE and the PBC have promoted many endeavors in order to facilitate realization of this "national challenge." A real manifestation of policy 
changes is evident in the gradually growing number of Haredi students but also in the diminishing intensity of resistance to higher education. Despite the satisfaction with the current trend, the CHE still does not consider the potential exhausted and there is need to establish an extensive infrastructure to provide a variety of professions with an employment horizon through a more extensive geographical spread and the diversification of disciplines and institutions. Moreover, the CHE sees a need to expand the financial assistance provided to Haredi students through scholarships and loans. The CHE strives to raise the rate of higher education among the Haredi community, in a manner appropriate for them.

Nonetheless, it is important to remain aware that exhausting the full potential of this population might harm and detract from the quality of all academic schooling. Global experience shows that religious students seeking to preserve their faith and identity establish their own institutions. These religious institutions have different and varied models but their main characteristic is the following of a uniform theological rationale, and most or a "critical" mass of their students come from the same religious group (Arthur, 2008). Policy shapers currently object to establishing unique institutions and the solution of integrating Haredi students in existing settings is supposed to constitute an intermediate route. In this context it is notable that, compared to other countries, Israel is a relatively small country and the addition of gradually more institutions might become a burden on the entire system of higher education, both financially and in the quality of studies. In contrast, gender division and separation between religious and secular populations also run the risk of a slippery slope, threatening to segment and split a society that is split to begin with. The situation in the field today is that, concurrent with the increase in unique campuses and programs there is also an increase in the number of Haredi students in regular institutions. Although their numbers are still small, in relative terms they have grown by tens of percents. Assumedly, in time, as higher education becomes a customary norm in Haredi society, we shall see less resistance to integration within regular existing institutions as well as stabilization of the number of students. Despite the forecasts for the significance of providing accessibility to higher education for Haredi students in Israel, we will probably see a similar process to that which occurred in the Israeli system of higher education in the 1990s, when it underwent a process of universalization and "popularization": At first there will be a significant increase in the proportion of Haredi students joining the system, and then it will level out.

\section{References}

Aghion, P., Dewatripont, M., Hoxby, P., Mas-Colell, A., \& Sapir, A. (2008). Higher aspirations: An agenda for reforming European universities. Brussels: Breugel.

Almog, O. (2012). Haredim in Israel - State of affairs. Jerusalem: Shmuel Neaman Institute for National Policy Research [Hebrew].

Arthur, J. (2008). Faith and secularisation in religious colleges and universities. Journal of Beliefs \& Values, 29(2), 197-202. http://dx.doi.org/10.1080/13617670802289692

Bar Ilan University (2014). Then and now. 2014/2015 calendar. Retrieved from http://www1.biu.ac.il/File/barilan60/calendar2015.pdf 


\section{Macrothink}

Issues in Social Science ISSN 2329-521X 2014, Vol. 2, No. 2

Caplan, K. (2007). The internal popular discourse in Israeli Haredi society. Jerusalem: Zalman Shazar Centre [Hebrew].

Caplan, K. (2010). Is the past indeed gone? Significance of the history of Haredi society for understanding the fabric of its life today. Seminar lecture. Israel Democracy Institute, Jerusalem [Hebrew].

Cohen, B. (2010). Army programs for specific populations: An ultra-orthodox perspective. Jerusalem: The Israel Democracy Institute [Hebrew].

Council for Higher Education /PBC. (2014). Israel's system of higher education 2014. Jerusalem [Hebrew].

Council for Higher Education. (2012a). Providing accessibility to higher education for unique sectors. Jerusalem: Council for Higher Education [Hebrew].

Council for Higher Education. (2012b). Israel's system of higher education 2012: On the route to growth. Jerusalem: Council for Higher Education [Hebrew].

Council for Higher Education. (2014). Israel's system of higher education 2014. Jerusalem: Council for Higher Education [Hebrew].

Council for Higher Education. Meeting protocol. (2013). Retrieved from http://www.news1.co.il/Archive /001-D-345045-00.html

Finkelman, Y. (2002). Haredi isolation in changing environments: A case study in Yeshiva immigration. Modern Judaism, 22(1), 61-82. http://dx.doi.org/10.1093/mj/22.1.61

Finkelman, Y. (2011). Ultra-orthodox/Haredi education. In H. Miller, L.D. Grant, \& A. Pomson (Eds.), International Handbook of Jewish Education (Vol. 2, pp. 23-41). Netherlands: Springer.

Friedman, J., Shaul-Mena, N., Fogel, N., Romanov, D., Amedi, D., Feldman, M. Shayek, R., Shifris, G. W., \& Portnoy, H. (2011). Measurement and estimates of the population of ultra-Orthodox Jews. Jerusalem: The Central Bureau of Statistics [Hebrew].

Friedman, M. (1991). Ultra-orthodox society: Sources, trends and processes. Jerusalem: The Jerusalem Institute for Israel Studies [Hebrew].

Ganss, G. E. (1954). Saint Ignatius' idea of a Jesuit university: A study in the history of Catholic education, including part four of the Constitutions of the Society of Jesus. Milwaukee: Marquette University Press.

Johnston, R. (1998). The University of the Future: Boyer revisited. Higher Education, 36, 253-272.

Katz, J. (1984). Halakhah and Kabbalah: Studies in the history of Jewish religion. Jerusalem: Magnes Press [Hebrew].

Katz, J. (1992). Halakhah in straits: Obstacles to orthodoxy at its inception. Jerusalem: Magnes Press [Hebrew]. 


\section{Macrothink}

Issues in Social Science ISSN 2329-521X 2014, Vol. 2, No. 2

Knesset (2014). Data on Academic Study Institutions for The Haredi Public. Research and Information Center: Jerusalem [Hebrew].

Kockelmans, J. J. (1986). Interd isciplinarity and the university: The dream and reality. Issues in Integrated Studies, 4, 1-6.

Levy, A. (2013). Description and analysis of the higher education budget in rcent years. Jerusalem: Knesset Research and Information Center [Hebrew].

Litfin, A. D. (2004). Conceiving the Christian college. Grand Rapids, MI: Wm. B. Eerdmans Publishing.

Lupo, J. (2003). Turning point in Ultra-Orthodox society: Vocational training and academic studies. Jerusalem: Floersheimer Institute for Policy Studies [Hebrew].

Lupo, J., \& Malhi, A. (2011). The attitude of Haredi yeshiva students to general studies and vocational studies. Jerusalem: Ministry of Industry, Trade, and Labor [Hebrew].

Malach, G. (2014). A "kosher" degree: Academic studies in the Haredi sector. Jerusalem: Floersheimer Institute for Policy Studies [Hebrew].

Malach, G., \& Cohen, B. (2011). The ultra-Orthodox to academia: Position paper on academic studies in ultra-Orthodox society. Tel Aviv: Israel Student Association [Hebrew].

Malhi, A. (2010). Employment in the Haredi community. Jerusalem: Economics and Research Authority, Ministry of Industry, Trade, and Labor [Hebrew].

Malhi, A., Cohen, B., \& Kaufmann, D. (2008). The ultra-orthodox: Fearing for their future Attitudes and obstacles relating to higher education in the ultra-orthodox sector. Jerusalem: The Jerusalem Institute for Israel Studies [Hebrew].

Neugershal, M. (2002). Why are they different - The ultra-orthodox and Israeli society. Jerusalem: Yahadut Mizavit Shona [Hebrew].

Pundak, R. (2013, April 25). Those who wish to enforce secular studies are not familiar with the ultra-Orthodox community. Calcalist [Hebrew].

Ravhon, U., \& Malach, G. (1999). Demographic trends in Israel. Jerusalem: Metzila Center [Hebrew].

Regev, E. (2013). Education and employment in the Haredi sector. In D. B. David (Ed.), State of the nation report - Society, economy and policy 2013 (pp. 1-39). Jerusalem: Taub Center for Social Policy Studies in Israel [Hebrew].

Schechter, S. (2006). Cracks in the ivory tower. Jerusalem: Zivonim [Hebrew].

Schuman, S. (2010). Seeing the light: Religious colleges in twenty-first-century America. Baltimore, MD: JHU Press.

Shahak, I., \& Mezvinsky, N. (1999). Jewish fundamentalism in Israel. London: Pluto Press. 


\section{Macrothink}

Issues in Social Science ISSN 2329-521X 2014, Vol. 2, No. 2

Sharma, S., \& Guest, M. (2013). Navigating religion between university and home: Christian students' experiences in English universities. Social \& Cultural Geography, 14(1), 59-79.

Spiegel, E. (2011). "Talmud Torah is equivalent for all": The ultra-orthodox (Haredi) education system for boys in Jerusalem. Jerusalem: The Jerusalem Institute for Israel Studies [Hebrew].

Spiegel, E. (2013). About outlooks and atmospheres: Haredi society as an interpretive community. Sugyot Hevratiot Beyisrael, 16, 7-40 [Hebrew].

Stadler, N. (2003). To subsist or to wait for a miracle: The Haredi 'catch' and its reflection in Torah and labor relations. In E. Sivan \& K. Caplan (Eds.), Israeli Haredim: Integration without assimilation? (pp. 9-29). Tel Aviv/Jerusalem: Van Leer Institute and Hakibbutz Hameuhad [Hebrew].

Thelin, J. R. (2011). A history of American higher education. Baltimore, MD: JHU Press.

Zatcovetsky, I., \& Gal, R. (2012). The way to integration: Policy paper for encouraging integration of the Haredi population in the labor market. Haifa: Shmuel Neaman Institute [Hebrew].

Zicherman, H. (2014). Black blue-white - Journey into Haredi society in Israel. Tel Aviv: Yediot Sfarim [Hebrew].

\section{Note}

Note 1. See for example an excerpt from the CHE meeting protocol: http:/www.news1.co.il/Archive/001-D-345045-00.html

\section{Appendices}

\section{Appendix A. MAHARs established in 2013}

\begin{tabular}{|c|c|}
\hline Study Programs & Name of Institution \\
\hline $\begin{array}{l}\text { Preparatory program outside the campus and studies in the } \\
\text { university's regular programs }\end{array}$ & Hebrew University \\
\hline $\begin{array}{l}\text { Computer sciences, optometry, biotechnology, media and } \\
\text { politics, management }\end{array}$ & $\begin{array}{l}\text { Hadassah } \quad \text { Academic } \\
\text { College }\end{array}$ \\
\hline Electronics and electrical engineering, software engineering & Sami Shamoon \\
\hline Software engineering & $\begin{array}{l}\text { College of Engineering } \\
\text { Jerusalem }\end{array}$ \\
\hline $\begin{array}{l}\text { Social work, computer sciences, economics and banking, } \\
\text { economics and management }\end{array}$ & $\begin{array}{l}\text { Ashkelon } \\
\text { College }\end{array}$ \\
\hline Art and architecture & Bezalel \\
\hline To be determined & Technion \\
\hline $\begin{array}{l}\text { Optometry, computer sciences, psychology, sociology, } \\
\text { economics, accounting }\end{array}$ & Bar Ilan University \\
\hline Nursing & Ruppin Academic Center \\
\hline
\end{tabular}


Appendix B. Growth trends in Haredi students from 2006-2016 (from: CHE, 2014).

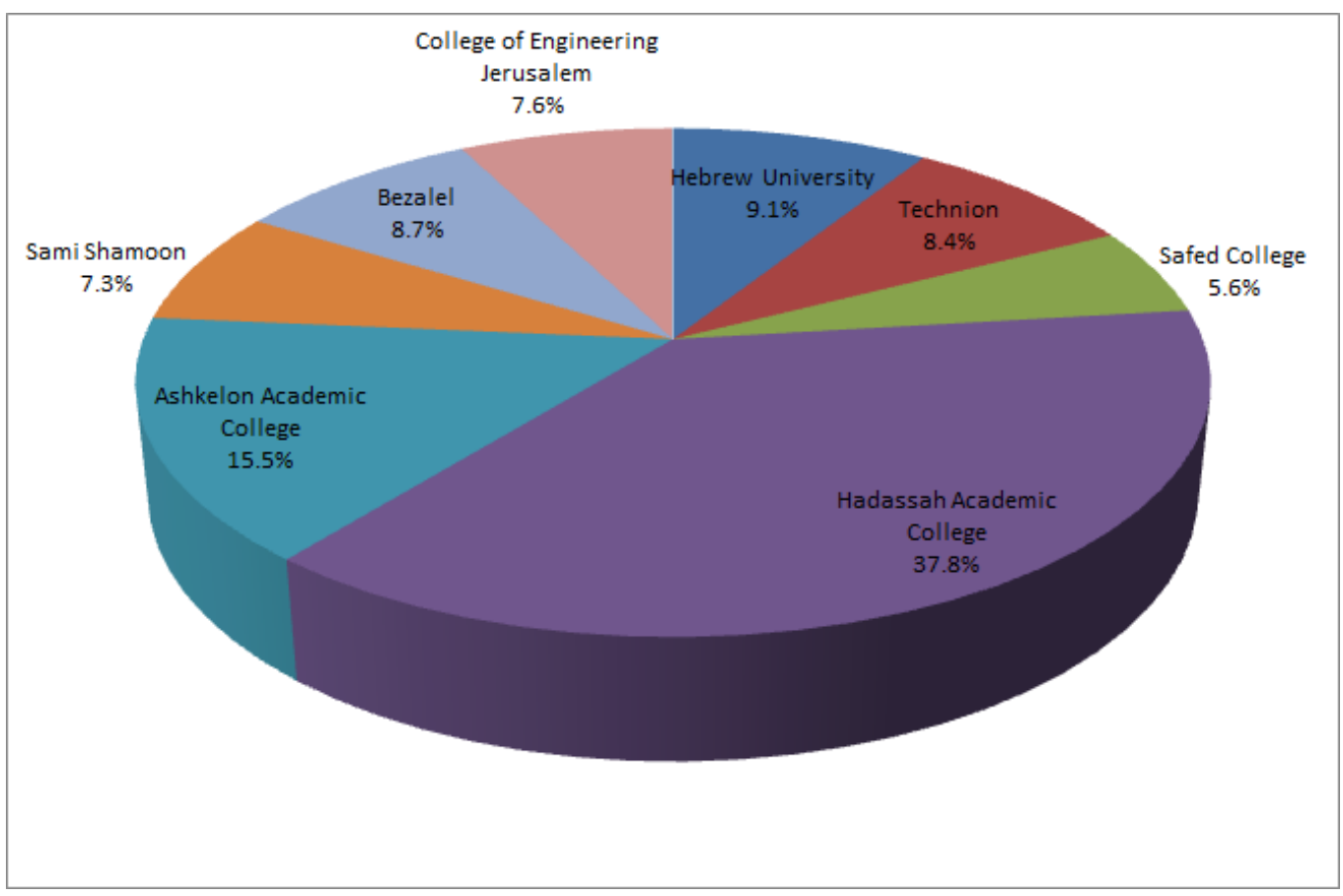

